\title{
Penggunaan Antiparasit Ivermectin pada Ternak: Antara Manfaat dan Risiko
}

\author{
Antiparasitic Ivermectin in Livestock: Between Benefits and Risks
}

\section{Yanuartono, S. Indarjulianto, A. Nururrozi, S. Raharjo, dan H. Purnamaningsih}

\author{
Departemen Ilmu Penyakit Dalam, Fakultas Kedokteran Hewan Universitas Gadjah Mada. \\ Jl. Fauna No.2, Karangmalang, Depok, Sleman. 55281 Yogyakarta \\ Tel : +62-274-560862, Fax +62-274-560861 \\ Corresponding author: yanuartono@ugm.ac.id
}

\begin{abstract}
Ivermectin belongs to macrocyclic lactones and is currently one of the most widely used antiparasitic drugs worldwide since its efficacy is well established. Ivermectin is highly active against a wide spectrum of nematode species, including most larvae, adult forms and also highly effective against many arthropod parasites of livestock animals. All ectoparasites are susceptible to ivermectin, including mites, ticks and biting flies. Toxicity to ivermectin is rarely found in livestock. Ivermectin poisoning is usually caused by mismanagement of medication by farmers in the form of excessive doses of ivermectin. The signs of toxicosis are mydriasis and depression, followed by ataxia, recumbency, and death. Symptomatic and supportive therapy can be given to suppress the effects of poisoning, however the most appropriate treatment is antidotes administration such as picrotoxin or physostigmine.
\end{abstract}

Key words: Ivermectin, antiparasitic, nematode, toxicity, depression, antidote

\begin{abstract}
ABSTRAK
Ivermectin termasuk dalam kelompok macrocyclic lactones dan saat ini merupakan salah satu antiparasit yang paling banyak digunakan di seluruh dunia karena sudah terbukti kemanjurannya. Ivermectin merupakan antiparasit spektrum luas spesies nematoda, termasuk sebagian besar larva, bentuk dewasa dan juga sangat efektif terhadap banyak parasit arthropoda hewan ternak. Semua ektoparasit rentan terhadap ivermectin, termasuk tungau, kutu, dan lalat penggigit. Keracunan yang disebabkan ivermectin jarang ditemukan pada hewan ternak. Keracunan biasanya disebabkan kesalahan manajemen pengobatan oleh peternak dalam bentuk pemberian ivermectin dengan dosis yang berlebihan. Gejala keracunan berupa midriasis dan depresi, diikuti oleh ataksia, berbaring dan kematian. Terapi simtomatis maupun suportif dapat diberikan untuk menekan efek keracunan, namun pengobatan yang paling tepat adalah dengan pemberian antidota seperti picrotoxin atau physostigmine.
\end{abstract}

Kata kunci: Ivermectin, antiparasit, nematoda, toksisitas, depresi, antidota

\section{PENDAHULUAN}

Ivermectin ditemukan pada tahun 1975 dan pertama kali dipasarkan secara komersial oleh Merck Sharp and Dohme untuk pengobatan parasit pada tahun 1981 (Steel, 1993; Kita et al., 2007; Campbell, 2012). Ivermectin termasuk dalam golongan macrocyclic lactone dengan berat molekul tinggi yang dihasilkan oleh Streptomyces avermitilis dan memiliki struktur mirip dengan antibiotika golongan makrolida namun tidak memiliki aktivitas anti bakteri (Campbell et al., 1983; Chhaiya et al., 2012). Sampai saat ini ivermectin merupakan salah satu antiparasit yang paling efektif dan banyak digunakan karena memiliki aktivitas spektrum luas terhadap berbagai macam endoparasit dan ektoparasit, terutama nematoda dan arthropoda (Geary, 2005; Omura, 2008). Kemampuan efektif terhadap endoparasit maupun ektoparasit menjadikan ivermectin disebut juga sebagai endecticides (Prichard et al., 2012; Campbell, 2016). Pada awalnya, ivermectin dikembangkan untuk pengobatan pada hewan ternak maupun hewan kesayangan untuk mengatasi infestasi nematoda gastrointestinal. Saat ini ivermectin telah banyak sekali digunakan, namun karena parameter farmakokinetik ivermectin sangatlah luas sehinga banyak faktor yang dapat mempengaruhi konsentrasi 
obat dalam plasma (Gonzalez et al., 2009; Panahi et al., 2015). Faktor-faktor tersebut antara lain adalah spesies, rute pemberian obat, larutan pembawa obat, berat badan, status fisiologis, jenis dan volume asupan pakan (Page et al., 2000; Leon-Vizcaino et al., 2001; Mestorino et al., 2003; Rahman et al., 2017). Banyaknya faktor tersebut mengakibatkan sulitnya melakukan ekstrapolasi data antar spesies sehingga faktor tersebut harus menjadi dasar pertimbangan pengambilan keputusan oleh praktisi dalam terapi menggunakan ivermectin (Gonzalez et al., 2009). Tanpa mempertimbangkan faktor faktor tersebut kemungkinan akan mengakibatkan kejadian keracunan pada hewan hewan yang diterapi dengan Ivermectin.

Kejadian keracunan ivermectin telah dilaporkan pada sapi (Bhikane et al., 2017), kambing (Abdou and Sharkawy, 2004), domba (Foreyt, 1993), kuda (Swor et al., 2009), kucing (Muhammad et al., 2004), ikan (Thiripurasundari et al., 2014), singa afrika (Saqib et al., 2015), dan kura kura dalam penanganan keracunan ivermectin, berbagai sediaan obat telah digunakan dengan hasil yang bervariasi. Keracunan biasanya terjadi karena over dosis pemberian, rute pemberian dan pemberian untuk spesies yang peka terhadap ivermectin (Hopper et al., 2002). Sediaan yang dapat digunakan dalam penanganan kasus keracunan tersebut antara lain emulsi lipid (Bruenisholz et al., 2012), physostigmine (Hopper et al., 2002), deksametason (Dey et al., 2017), dan antibiotika (Clayton et al., 2012). Terapi suportif pada umumnya berupa cairan dekstrose (Bhikane et al., 2017), $\mathrm{NaCl}$ dan laktat ringer (Bruenisholz et al., 2012). Tulisan ini mencoba mengulas secara singkat manfaat dan risiko penggunaan Ivermectin sebagai obat antiparasit, baik endoparasit maupun ektoparasit pada ternak.

Struktur, Sifat dan Cara Kerja Ivermectin Ivermectin pada awalnya diperkenalkan sebagai obat anti parasit, baik endoparasit maupun ektoparasit pada ternak dan hewan kesayangan Ivermectin adalah makrolida berasal dari Streptomyces avermitilis dan merupakan campuran dari dua avermectin yang dimodifikasi secara kimia dengan kandungan 22,23dihydroavermectin- Bla sebesar $80 \%$ dan 22,23-dihydroavermectin-B1b sebesar 20\% (Cerkvenik et al., 2001; Gonzalez et al., 2009). Sifat sangat lipofilik menyebabkan ivermectin dapat terdistribusi secara luas dengan volume distribusi (Vd) yang luas pada semua spesies. Kondisi tersebut mengakibatkan adanya kecenderungan Ivermectin akan terakumulasi dalam jaringan lemak yang berfungsi sebagai reservoir obat sehingga konsentrasi ivermectin tertinggi terdapat pada hati dan jaringan lemak serta terendah pada otak (Juarez et al., 2018). Saat ini Ivermectin memiliki banyak famili seperti doramectin dari strain mutan Streptomyces avermitilis, selamycin (derivat doramectin), nemadectin (Streptomyces cyanogriseus)., moxidectin (derivat nemadectin), milbemycin oxime yang berasal dari makrosiklik lactone milbemycin dan eprinomycin yang merupakan derivat ivermectin (Shoop et al., 2001; Cobb and Boeckh, 2009; Xiang et al., 2010; Prichard et al., 2012; Lespine, 2013).

Ivermectin bekerja pada sistem saraf dan fungsi otot sehingga mengakibatkan kelumpuhan dan kematian parasit (Campbell and Benz, 1984; Ludmerer et al., 2002). Menurut Aranzazu et al. (2007) Ivermectin bekerja dengan cara mengeluarkan dan mengikat Gamma Amino Butyric Acid (GABA) yang berfungsi memblokir impuls syaraf perifer dan otot polos parasit. Wolstenholme (2011) dan Yates et al. (2003) menambahkan bahwa Ivermectin akan melepaskan dan mengikat $\alpha$ subunit sebagai reseptor glutamate-gated chloride channels (GluCl) di sinapsis saraf tertentu yang mengakibatkan terjadinya penghambatan proses makan, fekunditas dan motilitas dari endoparasit. Glutamate-gated chloride channels (GluCl) merupakan anggota spesifik dari famili Cys-loop dari ligandgated ion channels yang terdapat pada syaraf dan miosit pada invertebrata. Sifat Ivermectin sebenarnya tidak mudah 
menembus otak dan cairan tulang belakang sehingga tingkat toksisitasnya rendah. Metabolisme Ivermectin terjadi di dalam hati dan kebanyakan peletkskresikan melalui feses serta dalam jumlah lebih kecil peletkskresikan melalui urin. Menurut Prasad and Koley ( 2006), ivermectin memiliki batas keamanan paling rendah 10 kali lipat dari dosis minimal $(0,2 \mathrm{mg} / \mathrm{kg} \mathrm{BB})$ untuk sapi dewasa. Lebih lanjut, menurut Patel et al. (2018), pedet jauh lebih sensitif terhadap pengobatan dengan ivermectin dan jika terjadi overdosis prognosanya lebih jelek dibandingkan dengan sapi dewasa.

\section{Ivermectin untuk Pengobatan Parasit pada Ternak}

Infeksi endoparasit maupun ektoparasit merupakan kejadian sangat umum pada ternak ruminansia di seluruh dunia. Infeksi parasit adalah faktor utama yang bertanggung jawab terhadap kerugian ekonomi melalui penurunan produktivitas serta peningkatan mortalitas. Parasit akan menyebabkan ternak kehilangan berat badan, penurunan asupan pakan (Radostits et al., 2000), penurunan efisiensi pakan (Ilyas et al., 2016), pubertas tertunda, penurunan tingkat kesuburan, tingkat kelahiran rendah (Rahman and Samad, 2010), penurunan kekebalan tubuh, rentan terhadap masuknya agen penyakit lain ataupun gangguan kesehatan lain yang dapat memperburuk kondisi secara keseluruhan (Raunelli and Gonzales 2009., Zalizar, 2017). Kontrol terhadap infestasi parasit pada kelompok ternak ruminansia tersebut sangat bergantung pada ketersediaan dan jenis obat anthelmintik. Saat ini, obat obat antiparasit baik endoparasit atau ektoparasit pada ruminansia dengan berbagai macam produk telah banyak beredar dan digunakan di lapangan. Antara 1960 dan 1990, industri farmasi mengalami kemajuan yang pesat dalam mengembangkan senyawa antiparasit dengan spektrum aktivitas dan tingkat keamanan obat yang tinggi (McKellar and Jackson, 2004). Pada tahun tahun tersebut telah dikembangkan tiga kelas obat anthelmintik dengan cara kerja yang berbeda untuk ruminansia seperti benzimidazoles (Jaeger and Carvalho-Costa, 2017), imidothiazoles (Louw, 1995), tetrahydropyrimidines dan macrocyclic lactones (De Graef et al., 2013).

Saat ini antiparasit baik endoparasit maupun ektoparasit telah lazim digunakan baik dalam pengobatan dan pencegahan infeksi parasit pada ruminansia besar maupun kecil. Metode aplikasi yang digunakan berupa injeksi dan per oral dalam bentuk cair maupun padat (Laffont et al., 2001; Bousquet-Melou et al., 2011). Produk antiparasit yang beredar di pasaran banyak dimanfaatkan untuk kontrol, perawatan dan pengobatan telah banyak mencapai keberhasilan selama tiga dekade terakhir terutama sejak dikenalkannya produk macrocyclic lactone seperti ivermectin. Ivermectin merupakan agonis untuk penghambatan neurotransmitter gammaaminobutyric acid (GABA) dan dapat diberikan secara oral, topikal atau dengan injeksi (Bloom and Matheson, 1993). Produk tersebut sampai saat ini telah mendominasi pasar sebagai antiparasit yang paling banyak diandalkan. Menurut Stapley and Woodruff (1982) serta Roberson (1988), hampir semua nematoda gastrointestinal dan paru-paru serta ektoparasit sapi, domba, kuda dan babi secara efektif dapat dibasmi dengan menggunakan Ivermectin. Namun demikian, pengobatan Ivermectin tidak efektif terhadap protozoa, cacing hati dan cacing pita karena neurotransmisi mereka tidak diperantarai oleh GABA (Campbell et al., 1983).

Penelitian maupun pengobatan pada ternak ruminansia di lapangan dengan menggunakan ivermectin telah banyak dilakukan, baik terhadap endoparasit maupun ektoparasit (Tabel 1). Tabel ini menunjukkan bahwa Ivermectin telah digunakan secara luas pada ternak sapi potong, sapi perah, kambing, domba. Dari tabel 1 dapat dilihat bahwa aplikasi Ivermectin pada ternak ruminansia melalui oral atau SC. 
Tabel 1. Penggunaan Ivermectin tunggal atau kombinasi untuk terapi bermacam ternak ruminansia

\begin{tabular}{|c|c|c|c|}
\hline Jenis ternak & Dosis dan rute pemberian & Sasaran & Pustaka \\
\hline Sapi potong & Ivermectin $0 / 5 \mathrm{mg} / \mathrm{kg}$ oral & Nematodirus spathiger & Mirhadi et al., 2011 \\
\hline Sapi potong & $\begin{array}{l}\text { Ivermectin } \mathrm{SC}(0,2 \mathrm{mg} / \mathrm{kg}) \text { dan } \\
\text { ricobendazole } \mathrm{SC}(3,75 \mathrm{mg} / \mathrm{kg})\end{array}$ & $\begin{array}{l}\text { Haemonchus } \quad \text { spp. } \quad \text { dan } \\
\text { Cooperia spp. }\end{array}$ & Canton et al., 2017 \\
\hline Sapi potong & $\begin{array}{l}\text { Ivermectin SC }(0.2 \\
\mathrm{mg} / \mathrm{kg})\end{array}$ & Ektoparasit dan endoparasit & Ahammed et al., 2016 \\
\hline Sapi potong & Ivermectin SC $0.2 \mathrm{mg} / \mathrm{kg} \mathrm{BB}$ & Anopheles coluzzii & Pooda et al., 2015 \\
\hline Sapi potong & $\begin{array}{l}\text { Ivermectin } 10 \mathrm{mg}(\mathrm{SC})+ \\
\text { clorsulon } 100 \mathrm{mg} \text { dalam } 1 \mathrm{~mL} \\
(\mathrm{SC})+250 \mathrm{mg} \text { nitroxynil } \\
\text { dalam } 1 \mathrm{~mL}(\mathrm{SC})\end{array}$ & $\begin{array}{l}\text { Fasciola sp. Paramphistomum } \\
\text { sp. }\end{array}$ & Islam, 2013 \\
\hline Sapi perah & Ivermectin SC $0.2 \mathrm{mg} / \mathrm{kg} \mathrm{BB}$ & Stephanofilaria & Senthilkumar et al., 2016 \\
\hline Sapi perah & Ivermectin SC $0.2 \mathrm{mg} / \mathrm{kg} \mathrm{BB}$ & $\begin{array}{l}\text { Hypoderma bovis dan } \\
\text { Hypoderma lineatum }\end{array}$ & Otranto et al., 2016 \\
\hline Sapi perah & Ivermectin SC $0.2 \mathrm{mg} / \mathrm{kg} \mathrm{BB}$ & $\begin{array}{l}\text { Ostertagia ostertagidan } \\
\text { Cooperia oncophora }\end{array}$ & $\begin{array}{l}\text { Pena-Espinoza et al., } \\
2016\end{array}$ \\
\hline Kambing & Ivermectin SC $200 \mu \mathrm{g} / \mathrm{kg} \mathrm{BB}$ & Sarcoptic mange & $\begin{array}{l}\text { Wosu and Onyeabor, } \\
2015\end{array}$ \\
\hline $\begin{array}{l}\text { Kambing } \\
\text { Kambing }\end{array}$ & $\begin{array}{l}\text { Ivermectin SC } 0.2 \mathrm{mg} / \mathrm{kg} \\
\text { Ivermectin } \mathrm{S} / \mathrm{C} \text { (at } 0.2 \mathrm{mg} / \mathrm{kg} \\
\mathrm{BB}) \text { dan Clorsulon } \mathrm{S} / \mathrm{C} \mathrm{(2} \\
\mathrm{mg} / \mathrm{kg} \text { body weight) }\end{array}$ & $\begin{array}{l}\text { Sarcoptes scabies var caprae } \\
\text { gastro-intestinal nematodosis, } \\
\text { fasciolosis dan amphistomosis }\end{array}$ & $\begin{array}{l}\text { Nwoha, } 2011 \\
\text { Kumar and Vatsya, } 2013\end{array}$ \\
\hline $\begin{array}{l}\text { Domba dan } \\
\text { kambing }\end{array}$ & $\begin{array}{l}\text { Ivermectin SC }(200 \mu \mathrm{g} / \mathrm{kg}) \mathrm{BB} \\
+\quad \text { Doramectin } 1 \% \quad \mathrm{SC} \\
(300 \mu \mathrm{g} / \mathrm{kg}) \quad, \quad 0.5 \% \quad \text { larutan } \\
\text { Trichlorophone dipping }\end{array}$ & $\begin{array}{l}\text { Psoroptes ovis, } \text { Sarcoptes } \\
\text { scabiei var. ovis }\end{array}$ & Zaman et al., 2017 \\
\hline Sapi potong & $\begin{array}{l}\text { Ivermectin SC, } 0.2 \mathrm{mg} / \mathrm{kg} \text { BB. } \\
\text { dan Streptopen IM, } 0.5 \mathrm{~g} / 50 \mathrm{~kg}\end{array}$ & myiasis & Rahman et al., 2009a \\
\hline Domba & $\begin{array}{l}\text { Ivermectin } \mathrm{SC}, 0.2 \mathrm{mg} / \mathrm{kg} \mathrm{BB} .+ \\
\text { albendazole } \\
3.8 \mathrm{mg} / \mathrm{kg} \text { intra ruminal }\end{array}$ & Nematoda gastrointestinal & Alvarez et al., 2008 \\
\hline domba & $\begin{array}{l}\text { Ivermectin } \mathrm{SC}, 0.2 \mathrm{mg} / \mathrm{kg} \mathrm{BB} \\
\text { dan ivermectin implant } 620 \mathrm{mg}\end{array}$ & Psoroptes sp. & Boyce et al., 1992 \\
\hline Domba & $\begin{array}{l}\text { Ivermectin } 1 \mathrm{ml} / 50 \mathrm{~kg} \text {, } \\
\text { + albendazole } 1 \mathrm{ml} / 5 \\
\mathrm{~kg} \text { BB peroral. }\end{array}$ & Ostertagia $s p$ & Puspitasari et al., 2015 \\
\hline
\end{tabular}

Dalam beberapa kasus, ivermectin dapat dikombinasikan dengan antiparsit yang lain seperti albendazole, streptopen, ricobendazole dan benzenesulphonamide seperti clorsulon. Kombinasi beberapa anthelmentik dengan mekanisme kerja serta resistensi yang berbeda telah tersedia secara luas di seluruh dunia untuk mengendalikan infeksi parasit pada ruminansia (Entrocasso et al., 2008; Abbott et al., 2009). Kombinasi anthelmintik tersebut diharapkan secara efektif mampu mengontrol infestasi nematoda dan menurunkan risiko munculnya resistensi tunggal maupun multiresisten dan memperlambat perkembangan resistensi parasit terhadap obat tersebut (Bartram et al., 2012).

Boyce et al. (1992) menggunakan ivermectin yang dikombinasikan dengan sustained-release implant yang mengandung $620 \mathrm{mg}$ Ivermectin untuk terapi infestasi ektoparasit Psoroptes sp. pada desert bighorn sheep jantan. Ivermectin implant diberikan $\mathrm{SC}$ pada 
sisi kiri leher domba. Pemberian kombinasi obat terebut sangat efektif untuk membasmi Psoroptes sp. pada domba. Menurut Jackson (1989) dan Miller et al. (1983) keuntungan menggunakan Ivermectin sustained-release implant adalah obat dapat bertahan dalam serum dengan jangka waktu yang cukup lama sehingga mampu mencegah reinfestasi parasit. Penelitian dengan menggunakan kombinasi antara ivermectin dengan albendazole telah dilakukan untuk pemberantasan Haemonchus contortus pada domba di Bogor, Jawa barat (Puspitasari et al., 2016). Hasil penelitiannya menunjukkan bahwa kombinasi ivermectin dengan albendazole lebih efektif jika dibandingkan dengan pengobatan tunggal albendazole. Kumar and Vatsya (2013) menggunakan kombinasi Ivermectin $(0.2 \mathrm{mg} / \mathrm{kg} \quad \mathrm{BB})$ dengan Clorsulon (2 mg/kg BB) secara SC untuk infeksi cacing Haemonchus, Oesophagostomum, Trichostrongylus spp. dan Fasciola gigantica pada kambing betina lokal di India. Hasil pengobatan menunjukkan kombinasi tesebut sangat efektif digunakan untuk mengendalikan nematodosis dan fasciolosis pada ruminansia kecil. Rahman et al. (2009b) menguji potensi ivermectin dibandingkan dengan obat obat herbal dadmardan (Cassia alata) dan neem (Azadiracta indica) secara topikal untuk pengobatan infestasi ektoparasit pada pedet dan kambing. Hasil penelitiannya menunjukkan bahwa pengobatan ivermectin lebih efektif dibandingkan dengan obat herbal dadmardan (Cassia alata) dan neem (Azadiracta indica).

Hasil penelitian dan praktik pengobatan di lapangan menunjukkan bahwa ivermectin atau ivermectin dengan berbagai kombinasi obat yang lain secara efektif mampu mengendalikan infestasi endoparasit maupun ektoparasit. Selain hal tersebut, obat obat antiparasit mampu menurunkan angka kejadian penyakit pada ternak dan pada akhirnya dapat menurunkan angka kerugian ekonomi pada industri peternakan.

\section{Gejala Keracunan Ivermectin}

Ivermectin merupakan antiparasit yang memiliki spektrum cukup luas tetapi juga menyebabkan efek samping yang dapat membahayakan terutama jika pemberiannya melebihi dosis atau diberikan pada spesies non target (Siroka and Svobodova, 2013). Kasus keracunan ivermectin telah banyak dilaporkan pada hewan hewan seperti babi, sapi, kuda, kucing, anjing dan kura kura (Teare and Bush, 1983; Burrough, 1986., Sanford et al., 1988; Neff et al., 2004; Muhammad et al., 2004; Dey et al., 2017). Keracunan Ivermectin telah banyak diteliti dalam bidang kedokteran hewan dan pada umumnya hal tersebut akibat dari pemberian dengan dosis yang berlebihan dengan gejala klinis yang muncul tergantung pada derajad paparan dan umur hewan. Tingkat keparahan keracunan hewan ternak terhadap ivermectin tergantung pada rute pemberian dan sifat farmakokinetiknya. Ivermectin sangat larut dalam lemak, volume distribusi yang besar dan akan terkonsentrasi dalam jaringan lemak sehingga waktu paruh eliminasi menjadi panjang (Chittrakarn et al., 2009., Merola and Eubig, 2012). Absorbsi pada pemberian sub cutan (SC) akan lebih lambat jika dibandingkan dengan pemberian oral, namun ketersediaan dalam plasma menjadi lebih tinggi, durasi waktu bekerja lebih lama sehingga lebih efektif dalam kemampuan pengobatan (Lanusse et al., 1997; Molento et al., 2004).

Gejala klinis dari berbagai hewan yang muncul akibat keracunan ivermectin dapat dilihat pada tabel 2. Kejadian keracunan Ivermectin di lapangan ternyata lebih banyak menimpa pada hewan-hewan seperti singa, kuda maupun bagal. Kejadian tersebut tampaknya disebabkan oleh penggunaan dosis ivermectin yang sebenarnya direkomendasikan untuk pengobatan parasit pada ternak ruminansia (Reinemeyer and Courtney, 2001). Dosis Ivermectin untuk hewan hewan tersebut diatas masih belum ditentukan sehingga rujukan yang digunakan belum terbukti tingkat keamanannya. 
Tabel 2. Gejala keracunan ivermectin pada hewan

\begin{tabular}{|c|c|c|c|c|}
\hline Hewan & Jenis obat & Dosis & Gejala & Pustaka \\
\hline Anak babi & Ivermectin & $300 \mu \mathrm{g} / \mathrm{kg} \mathrm{SC}$ & muntah, gemetar, ataksia, ambruk & $\begin{array}{l}\text { Sanford et al., } \\
1988\end{array}$ \\
\hline Pedet & Ivermectin & $\begin{array}{l}600 \mathrm{mcg} / \mathrm{kg}, \\
\mathrm{SC}\end{array}$ & $\begin{array}{l}\text { depresi, ataksia, liur berlebihan, } \\
\text { takikardia, gangguan pernapasan dan } \\
\text { diare }\end{array}$ & Basudde, 1989 \\
\hline Bagal & Ivermectin & $4.5 \mathrm{mg} / \mathrm{kg}$ oral & $\begin{array}{l}\text { kelemahan umum, depresi, ataksia, } \\
\text { tidak mampu berdiri dan mengalami } \\
\text { kebutaan. }\end{array}$ & $\begin{array}{l}\text { Plummer et al., } \\
2006\end{array}$ \\
\hline Kuda & Ivermectin & $0.2 \mathrm{mg} / \mathrm{kg}$ oral & $\begin{array}{l}\text { ataksia, disfungsi syaraf muka, } \\
\text { midriasis, pireksia }\end{array}$ & $\begin{array}{l}\text { Norman et al., } \\
2012\end{array}$ \\
\hline Kuda poni & Ivermectin & $\begin{array}{l}5.4 \mathrm{mg} / \mathrm{kg} \\
\text { oral }\end{array}$ & $\begin{array}{l}\text { kelemahan umum, stupor, pulsus } \\
\text { lemah, reflek palpebra dan pupil } \\
\text { menghilang, pingsan }\end{array}$ & $\begin{array}{l}\text { Bruenisholz et } \\
\text { al., } 2012\end{array}$ \\
\hline $\begin{array}{l}\text { Singa } \\
(\text { Panthera leo })\end{array}$ & Doramectin & $\begin{array}{l}0.2 \mathrm{mg} / \mathrm{kg} \text { and } \\
0.5 \mathrm{mg} / \mathrm{kg} \mathrm{SC}\end{array}$ & ataksia, halusinasi dan mydriasis & $\begin{array}{l}\text { Lobetti and } \\
\text { Caldwell, } 2012\end{array}$ \\
\hline $\begin{array}{l}\text { Singa } \\
(\text { Panthera leo })\end{array}$ & Ivermectin & $3 \mathrm{mg} / \mathrm{kg}$, oral & $\begin{array}{l}\text { gangguan syaraf akut, ataksia, } \\
\text { halusinasi, kejang, disorientasi dan } \\
\text { kebutaan bilateral. }\end{array}$ & $\begin{array}{l}\text { Saqib et al., } \\
2015\end{array}$ \\
\hline Kambing & Ivermectin & $2 \mathrm{mg} / \mathrm{kg} \mathrm{SC}$ & ataksia, depresi dan tremor & $\begin{array}{l}\text { Abdou and } \\
\text { Sharkawy, } 2004\end{array}$ \\
\hline
\end{tabular}

Saqib et al. (2015) menambahkan bahwa sampai saat ini belum ada penelitian yang dilakukan untuk mengukur seberapa dosis ivermectin yang dapat mengakibatkan keracunan pada singa. Dengan demikian data dosis terapi yang jelas dan dapat direkomendasikan untuk pengobatan parasit pada singa masih belum dapat ditentukan secara pasti. Kejadian keracunan ivermectin jarang terjadi pada hewan ternak produksi seperti sapi potong, sapi perah, kambing maupun domba. menurut Patel et al. (2018), gejala keracunan Ivermectin pada pedet akan muncul jika diberikan ivermectin dengan dosis 3 kali lipat dari dosis terapi yang dianjurkan. Hewan muda pada umumnya lebih sensitif bereaksi terhadap pemberian overdosis dengan prognosa yang jelek jika dibandingkan dengan yang dewasa. Pada tabel 2 terlihat bahwa gejala keracunan ivermectin yang paling menciri adalah kelemahan umum, kejang, ataksia dan mydriasis. Menurut Merola and Eubig (2012) ivermectin pada konsentrasi tinggi dapat mengakibatkan depresi dan ataksia. Efek toksik Ivermectin sangat terkait interaksinya dengan glikoprotein-P yang menghambat aksesnya ke SSP (Wolstenholme, 2011.,
Bruenisholz et al., 2012). Lebih lanjut, pada hewan hewan yang baru lahir atau kuda umur dibawah 4 bulan masih belum mampu mengekspresikan glikoprotein-P sehingga terjadi kegagalan penghambatan penetrasi ivermectin ke SSP (Watchko, et al., 2001; Plummer et al., 2006).

Patel et al. (2018) melaporkan kasus keracunan akibat overdosis ivermectin pada pedet. Dalam kasus tersebut pedet dengan berat badan $30 \mathrm{~kg}$ diberi pengobatan ivermectin (100mg/bolus) yang dikombinasikan dengan fenbendazole (3000mg/ bolus). Gejala klinis yang teramati adalah anoreksi, salivasi, rambut kusam, ataksia, selaput lendir pucat, midriasis, tidak adanya refleks pupil, suhu tubuh normal, takikardia, tachypnoea, depresi, cara berjalan abnormal dan kemudian ambruk diikuti dengan tremor. Penelitian oleh Abdou and Sharkawy (2004) pada kambing yang diberi Ivermectin dengan dosis diatas level terapaeutik menunjukkan gejala klinis yang mirip dengan sapi. Gejala klinis yang muncul pada kambing tersebut antara lain ataksia, tremor, depresi, diarrhea, mydriasis dan 
kadang-kadang dapat berakibat fatal. Hasil pemeriksaan klinis pedet akibat keracunan ivermectin yang diamati oleh Bhikane et al. (2017) juga menunjukkan kemiripan yaitu kelemahan umum, inkoordinasi saat berjalan, termor, adanya leleran hidung, saliva lengket, selaput lendir sianotik, suhu tubuh normal, peningkatan pulsus dan frekwensi nafas. Abdou and Sharkawy (2004) telah mempelajri efek toksik ivermectin terhadap kambing Balady. Dalam penelitiannya, Tiga puluh ekor kambing betina berumur tiga tahun, dibagi menjadi 3 kelompok, kelompok I dengan dosis teraupetik, kelompok II diberi dosis 10 kali lipat dosis terupetik dan kelompok kontrol tanpa pemberian ivermectin. Gejala klinis yang muncul pada kelompok II menunjukkan bahwa 2 kambing mengalami ataksia selama 4 hari, 12 jam setelah injeksi ivermectin, 2 ekor mengalami diare dan seekor menunjukkan gejala tremor ringan. Kambing lain pada kelompok II menunjukkan gejala depresi. Semua kambing dengan pemberian dosis teraupetik (kelompok I) tidak menunjukkan gejala keracunan.

Hasil penelitian maupun kasus kasus lapangan menunjukkan bahwa gejala klinis keracunan ivermectin pada umumnya terkait dengan sistem saraf pusat (Yas-Natan et al., 2003). Depresi neurologis, ataksia, midriasis, kebutaan, tremor, hipersalivasi dan jika melanjut hewan akan mengalami koma (Bloomquist, 2003., Gonzalez et al., 2007., Muller and Dwyer, 2016). Kebutaan biasanya bersifat sementara dan kemungkinan terkait dengan edema retina serta kelainan electroretinogram (Kenny et al., 2008). Kasus kasus keracunan ivermectin mengarah pada gejala klinis yang hampir sama dengan keracunan lain sehingga penelusuran sejarah pengobatan, anamnesa yang cermat serta pemeriksaan klinis harus dilakukan dengan seksama. Dari kasus keracunan dalam penelitian maupun kasus lapangan yang terdokumentasi, keracunan tersebut lebih banyak disebabkan oleh overdosis pengggunaan ivermectin yang tampaknya disebabkan karena praktek manajemen pengobatan yang tidak tepat.

\section{Pengobatan Keracunan Ivermectin}

Penelitian maupun studi kasus keracunan ivermectin pada ternak ruminansia tidak banyak dipublikasikan. Bhikane et al. (2017) berhasil melakukan terapi pada kasus pedet yang mengalami keracunan Ivermectin. Pengobatan yang diberikan berupa cairan pengganti dextrose $5 \% \quad 1$ liter/hari/iv, kombinasi amoksilin dan kloksasilin masing masing $10 \mathrm{mg} / \mathrm{kgBB} / \mathrm{iv}$, vitamin B kompleks $3 \mathrm{ml} / \mathrm{iv}$, chlorpheniramine maleate $0.2 \mathrm{mg} / \mathrm{kg} / \mathrm{im}$ dan dexamethasone $0.3 \mathrm{mg} / \mathrm{kg} / \mathrm{iv}$. Pengobatan diberikan sekali setiap hari selama 5 hari. pengobatan lain yang diberikan adalah etofylline $84.7 \mathrm{mg} / \mathrm{ml}$ dan theophylline $25.3 \mathrm{mg} / \mathrm{ml}$, masing masing $2 \mathrm{ml} / 2$ kali sehari. Kesembuhan mulai tampak pada hari ke 2 setelah pengobatan yang ditandai dengan hilangnya gejala klinis yang muncul.

Kasus keracunan pengobatan kombinasi fenendazole (3000 $\mathrm{mg}$ ) dengan ivermectin $(100 \mathrm{mg})$ pada pedet dapat diterapi dengan arang aktif (activated charcoal) $2 \mathrm{~g} / \mathrm{kgBB}$ peroral 2 kali sehari dan diazepam $0,5 \mathrm{mg} / \mathrm{kgBB} 2$ kali sehari. Terapi cairan pengganti diberikan selama 3 hari. Terapi lain yang diberikan adalah injeksi intramuskuler theophilin $6,6 \mathrm{mg} / \mathrm{kg} \mathrm{BB}$, chlorpheniramine maleate $0,5 \mathrm{mg} / \mathrm{kgBB}$ dan injeksi vitamin B kompleks $3 \mathrm{ml}$ masing masing selama 5 hari (Patel et al., 2018). Saqib et al. (2015) menggunakan injeksi emulsi lemak/intravenous lipid emulsion (ILE) yang mengandung 20\% minyak kedelai dan terapi suportif berupa larutan kristaloid isotonik $30 \mathrm{ml} / \mathrm{kg} \mathrm{BB}$ pada singa Afrika (Panthera leo) yang mengalami kebutaan akibat keracunan ivermectin. Merujuk pada penanganan kasus diatas, rekomendasi untuk terapi keracunan ivermectin meliputi terapi simptomatis, perawatan hewan yang seksama dan terapi suportif untuk mempercepat pemulihan kesehatan (Crandell and Weinberg, 2009). Meskipun pengobatan yang dilakukan pada kasus tersebut dianggap berhasil namun sebenarnya akan lebih tepat jika digunakan antidota seperti picrotoxin atau physostigmine. Kendala penggunaan 
antidota tersebut adalah mahal serta sulitnya diperoleh di lapangan dalam waktu yang cepat sehingga jika mengandalkan obat tersebut kemungkinan besar hewan telah mati karena pengobatan sudah terlambat. Pengobatan picrotoxin atau physostigmine sebagai antidota keracunan ivermectin telah banyak digunakan pada pada hewan kesayangan seperti anjing dan kucing (Sivine et al., 1985; Lovell, 1990; Muhammad et al., 2004). Hal tersebut tidaklah mengherankan karena antidota picrotoxin atau physostigmine lebih mudah diperoleh dikota kota besar dimana banyak pemilik hewan kesayangan.

\section{KESIMPULAN}

Ektoparasit maupun endoparasit akan menyebabkan ternak kehilangan berat badan, penurunan asupan pakan, penurunan efisiensi pakan dan penurunan kekebalan tubuh. Sampai saat ini, Ivermectin merupakan salah satu antiparasit yang sangat bermanfaat dalam memberantas parasit tersebut. Ivermectin dianggap paling efektif dan banyak digunakan karena memiliki aktivitas spektrum luas terhadap berbagai macam endoparasit dan ektoparasit, terutama nematoda dan arthropoda. Namun pada kenyataannya, penggunaan yang tidak sesuai aturan memiliki risiko akan mengakibatkan terjadinya keracunan ivermectin. Penggunaan yang sesuai aturan diharapkan memberikan dampak yang lebih menguntungkan dibandingkan dengan risiko yang ditimbulkannya.

\section{DAFTAR PUSTAKA}

Abbott, K. A., M. A. Taylor and L. A. Stubbings. 2009. SCOPS (Sustainable Control of Parasites in Sheep). A Technical Manual for Veterinary Surgeons and Advisers (thirded.), SCOPS, Malvern (2009) http://www.nationalsheep.org.uk/images/ stories/pdf/scopstechmanthree.pdf .26 Maret 2019

Abdou, K. A. and A. A. Sharkawy. 2004. Some toxicological stupelets on ivermectin in goats. Proceeding of the 20 Annual meeting of the Egyptian Society of toxicology. February $18-19,2004$. Bibliotheca Alexandria.

Ahammed, M., M. A., M. A. Ali, Ehsan and M. Mostafa. 2016. Efficacy of Ivermectin Against Gastrointestinal Nematodiasis and Ectoparasites in Crossbred Cattle in Bangladesh. Bangl. J. Vet. Med. 14 (2): 191-197.

Alvarez, L., A. Lifschitz, C. Entrocasso, J. Manazza, L. Mottier, B. Borda, G. Virkel and C. Lanusse. 2008. Evaluation of the interaction between ivermectin and albendazole following their combined use in lambs. J. vet. Pharmacol. Ther., 31(3): 230-239.

Aranzazu, G.C., M. Ana, P.M. Sahagu'n, J.D. Liebana, L.Z. Martinez, M.S. Vega, J Juan and G. Vieitez. 2007. The Pharmacokinetics and Metabolism of Ivermectin in Domestic Animal Species. Department of Biomedical Sciences. Veterinary Faculty, University of Leon. Spain.

Bartram, D.J., D.M. Leathwick, M.A. Taylor, T. Geurden and S. J. Maeder. 2012. The role of combination anthelmintic formulations in the sustainable control of sheep nematodes. Veterinary Parasitology. 186 (3-4): 151-158.

Basudde, C. D. K 1989. Clinical signs and biochemical changes in calves caused by injection of ivermectin. Veterinary Quarterly. 11(1): 29-32.

Bhikane, A. U., R. K. Jadhav and M. Anand. 2017. Successful Therapeutic Management of Ivermectin Toxicity in Deoni Calf. Dairy and Vet. Sci. J. 2(4):14.

Bloom, R.A. and J. C. Matheson III. 1993. Environmental assessment of avermectins by the US Food and Drug Administration. Veterinary Parasitology 48 (1-4): 281-294.

Bloomquist, J. R. 2003. Chloride channels as tools for developing selective 
insecticides. Arch. Insect Biochem. Physiol. 54 (4): 145-156.

Bousquet-Mélou, A., P. Jacquiet, H. Hoste, J. Clément, J. P. Bergeaud, M. Alvinerie and P. L. Toutain. 2011. Licking behaviour induces partial anthelmintic efficacy of ivermectin pour-on formulation in untreated cattle. Int $\mathrm{J}$ Parasitol. 41(5):563-569.

Boyce, W.M., J.A. Miller, D.A. Jessup and R.K. Clark. 1992.Use of Ivermectin Implants for the Treatment of Psoroptic Scabies in Free-RangingBighorn Sheep. Journal of Zoo and Wildlife Medicine. 23 (2): 211213.

Bruenisholz, H., J. Kupper, C. R. Muentener, A. Dally, T. Kraemer, H. Naegeli and C. C. Schwarzwald. 2012. Treatment of Ivermectin Overdose in a Miniature Shetland Pony Using Intravenous Administration of a Lipid Emulsion. J Vet Intern Med. 26 (2):407-411.

Burrough, S. 1986. Ivermectin toxicity in horses. New Zealand Veterinary Journal. 34 (8): 137-138.

Campbell, W.C. and G.W. Benz. 1984. Ivermectin: a review of efficacy and safety. J Vet Pharmacol Ther. 7(1):1-16.

Campbell, W.C. 2012. History of ivermectin and abamectin: with notes on the history of later macrocyclic lactone antiparasitic agents. Curr. Pharmacol. Biotechnol. 13(6):853-865.

Campbell, W.C. 2016. Lessons from the History of Ivermectin and Other Antiparasitic Agents. Annu. Rev. Anim. Biosci. 4:114.

Campbell, W. C., M. H., Fisher, E. O., Stapley, G. Albers-Scho"nberg and T. A. Jacob. 1983. Ivermectin: A potent new antiparasitic agent. Science, 221(4613):823-828.

Canton, C., L, Ceballos, C. Fiel, L. Moreno, P.D. Yagüez, G. Bernat, C. Lanusse and L. Alvarez. 2017. Resistant nematodes in cattle: Pharmaco-therapeutic assessment of the ivermectin- ricobendazole combination. Veterinary Parasitology. 234:40-48.

Cerkvenik, V., D.Z. Doganoc, V. Skubic, W.M.J. Beek and H.J. Keukens. 2001. Thermal and long-term freezing stability of ivermectin residues in sheep milk. Eur Food Res Technol. 213 (1):72-76.

Chhaiyaa, S. B., D. S., Mehtaa and B. C. Katariab. 2012. Ivermectin: pharmacology and therapeutic applications. Int J Basic Clin Pharmacol. 1(3): 132-139.

Chittrakarn, S., B. Janchawee, P. Ruangrut, S. Kansenalak, U. Chethanond, T. Kobasa and S. Thammapalo. 2009. Pharmacokinetics of Ivermectin in cats receiving a single subcutaneous dose. Res. Vet. Sci., 86(3): 503-507.

Chiu, S. H. L., M. L. Green, F. P. Baylis, D. Eline, A. Rosegay, H. Meriwether and T. A. Jacob. 1990. Absorption, tissue distribution, and excretion of tritiumlabeled Ivermectin in cattle, sheep, and rat. J. Agric. Food Chem. 38 (11): 20722078.

Clayton, L.A., J. Nelson, M.E. Payton, J.J. McDonnell, B.H. Rossi, K. King-Rahn and D. Woodburn. 2012. Clinical Signs, Management, and Outcome of Presumptive Ivermectin Overdose in a Group of Dendrobatid Frogs Journal of Herpetological Medicine and Surgery. 22 (1-2):5-11.

Cobb, R. and A. Boeckh. 2009. Moxidectin: a review of chemistry, pharmacokinetics and use in horses Parasites \& Vectors. 2(Suppl 2): S5.

Crandell, D. E. and G. L. Weinberg. 2009. Moxidectin toxicosis in a puppy successfully treated with intravenous lipids. J Vet Emerg Crit Care. 19(2):18186.

De Graef, J., E. Claerebout and P. Geldhof. 2013. Anthelmintic resistance of gastrointestinal cattle nematodes. Vlaams 
Peletrgeneeskundig Tijdschrift. 82 (1): 113-122.

Dey, S., N.P. Kurade, K. L. Khurana and A. Dan. 2017. Clinicobiochemical changes in ivermectin toxicity in Doberman pinscher pups. J Parasit Dis., 41(2):580 583

Entrocasso, C., $\quad$ L. Alvarez, J. Manazza, A. Lifschitz, B. Borda, G. Virkel, L. Mottier and C. Lanusse. 2008. Clinical efficacy assessment of the albendazoleivermectin combination in lambs parasitized with resistant nematodes. Vet. Parasitol. 155 (3-4):249-256.

Foreyt, W.J. 1993. Efficacy of in-Feed Formulation Ivermectin Against Psoroptes Sp. in Bighorn Sheep. Journal of Wildlife Diseases. 29 (1):85-89.

Geary, T.G. 2005. Ivermectin 20 years on: maturation of a wonder drug. Trends Parasitol. 21(11): 530-532.

Gonzalez, C.A., A.M. Sahagun Prieto, M. J. Peletz, N. Fernandez, M. Sierra and J. J. Garcia. 2007. Bioavailability of a commercial formulation of ivermectin after subcutaneous administration to sheep. Am. J. Vet. Res. 68 (1): 101-106.

Gonzalez, C.A., A.M. Sahagun Prieto, M. Jose Peletz Lie'bana, N.F. Martı'nez, M.S. Vega and J.J. Vieitez. 2009. The pharmacokinetics and metabolis of ivermectin in domestic animal species. The Veterinary Journal. 179 (1): 25-37.

Hopper, K., J. Aldrich and S.C. Haskins. 2002. Ivermectin Toxicity in 17 Collies. J Vet Intern. Med. 16(1):89-94.

Ilyas, N., M.M. Hossain, M.J.U. Bhuyan and M.M.H. Khan. 2016. Prevalence of Gastro-intestinal Nematodes Infection of Cattle in Bangladesh. AJPCT. 4(03):091097.

Islam, A. 2013. Comparative efficacy of ivermectin plus clorsulon and nitroxynil against naturally infected cattle. Eurasian Journal of Veterinary Science, 29(1): 4345.
Islam, S.T., M.Y. Ganaie, S.S. Kubra, R. Ali and A. K. Singh. 2017. Ivermectin Toxicity in a German Shepherd Cross Breed Dog: A Case Study. Int.J.Curr.Microbiol.App.Sci $\quad 6(11)$ : 1452-1455.

Jackson, H. C. 1989. Ivermectin as a systemic insecticide. Parasitol. Today, 5(5): 146156.

Jaeger, L.H. and F. A. Carvalho-Costa. 2017. Status of benzimidazole resistance in intestinal nematode populations of livestock in Brazil: a systematic review. BMC Veterinary Research. 13:358: 1-10.

Juarez, M., S. C. Alejandro and D. G. Alfonso. 2018. Review Article The multitargeted drug Ivermectin: from an antiparasitic agent to a repositioned cancer drug. Am J Cancer Res. 8 (2): 317-331.

Kenny, P.J., K.M. Vernau, B. Puschner and D.J. Maggs. 2008. Retinopathy associated with ivermectin toxicosis in two dogs. J Am Vet Med Assoc. 233 (2):279-284.

Kim, J. S. and E. C. Crichlow. 1995. Clinical signs of ivermectin toxicity and the efficacy of antigabaergic convulsants as antidotes for ivermectin poisoning in epileptic chickens. Vet Hum Toxicol. 37(2):122-126.

Kita, K., K. Shiomi and S. Omura. 2007. Advances in drug discovery and biochemical stupelets Trends Parasitol. 23 (5): 223-229.

Kumar, R.R. and S. Vatsya. 2013. Efficacy of Ivermectin - Clorsulon combination against mixed helminthic infection in goat - a case report. Veterinary Research International. 1(1): 31-32.

Laffont, C. M., M. Alvinerie, A. BousquetMélou and P. L. Toutain. 2001. Licking behaviour and environmental contamination arising from pour-on ivermectin for cattle. Int. J. Parasitol. 31(14):1687-1692.

Lanusse, C., A. Lifschitz, G. Virkel, L. Alvarez S. Sánchez, J. F. Sutra, P. Galtier and M. 
Alvinerie. 1997. Comparative plasma disposition kinetics of Ivermectin, moxidectin and doramectin in cattle. J Vet Pharmacol Ther. 20 (2): 91-99.

Leon-Vizcaıno, L., M. J., Cubero, E., GonzalezCapitel, M. A., Simon, L., Perez, M. R., Ruiz de Ybanez, J. M., Ortız., M. G. Candela and F. Alonso. 2001. Experimental Ivermectin Treatment Of Sarcoptic Mange and Establishment of A Mange-Free Population of Spanish Ibex. Journal of Wildlife Diseases. 37(4): 775785 .

Lespine, A. 2013. Lipid-like properties and pharmacology of the anthelmintic macrocyclic lactones Expert Opin. Drug Metab. Toxicol. 9(12):1-15.

Lo, P. K., D.W. Fink, J. B. Williams and J. Blodinger. 1985. Pharmacokinetic stupelets of Ivermectin: Effects of formulation. Vet. Res. Commun. 9 (1): 251-268.

Lobetti, G. and P. I. Caldwell. 2012. Doramectin toxicity in a group of lions (Panthera leo). J. S. Afr. Vet. Assoc. 83(1):89-92.

Louw, J.P. 1995. Anthelmintic sales in the Highveld region of Eastern Transvaal. Journal of the South African Veterinary Association. 66(2):66-70.

Lovell, R. A. 1990. Ivermectin and Piperazine Toxicoses in Dogs and Cats April 1990. Veterinary Clinics of North America Small Animal Practice. 20 (2):453-68.

Ludmerer, S.W., V.A. Warren, B.S. Williams, Y. Zheng, D.C. Hunt, M.B. Ayer, M.A. Wa llace, A.G. Chaudhary, M.A. Egan, P.T. Meinke, D.C. Dean, M.L. Garcia, D.F. C ully and M.M Smith. 2002. Ivermectin and nodulisporic acid receptors in Drosophila melanogaster contain both gamma-aminobutyric acid-gated Rdl and glutamate-gated $\mathrm{GluCl}$ alpha chloride channel subunits Biochemistry. 41 (20):6548-6560

McKellar, Q. A. and F. Jackson. 2004. Veterinary anthelmintics: old and new. Trends in Parasitology. 20 (10): 456-461.
Merola, V.M. and P.A. Eubig. 2012. Toxicology of Avermectins and Milbemycins (Macrocylic lactones) and the Role of PGlycoprotein in Dogs and Cats. Vet Clin North Am Small Anim Pract., 42(2): 122 .

Mestorino, N., E. Turic, J. Pesoa, A. J. Echeverri and J.O. Errecalde. 2003. Pharmacokinetics in plasma of ivermectin after its oral (solution and tablets) administration to sheep. J. vet. Pharmacol. Therap. 26(4): 307-309.

Miller, J. A., R. O. Drummond and D. D. Oehler. 1983. A sustained release ivermectin implant for livestock pest control. In: Roseman, T. J., and S. Z. Mansdorf (eds.). Controlled Release Delivery Systems. Marcel Dekker, New York, New York. Pp. 223236.

Mirhadi, K., G. Yagoob and S. Saeid. 2011. The effect of Ivermectin pour-on administration against natural Nematodirus spathiger infestations and prevalent rate of that in cattle. Afr. J. Microbiol. Res. 5(23): 3858-3861.

Molento, M. B., A. Lifschitz, J. Sallovitz, C. Lanusse and R. Prichard. 2004. Influence of verapamil on the pharmacokinetics of the antiparasitic drugs Ivermectin and moxidectin in sheep. J. Parasitol. Res., 92 (2): 121-127.

Muhammad, G., J. Abdul, M. Z. Khan and M. Saqib. 2004. Use of neostigmine in massive Ivermectin toxicity in cats. Vet Hum Toxicol. 46(1): 28-29.

Muller, K. R. and C. Dwyer. 2016. Suspected levamisole intoxication in calves. $\mathrm{N} \mathrm{Z}$ Vet J. 64 (4): 257-260.

Neff, M.W., K. R. Robertson, A. K. Wong, N. Safra, K.W. Broman, M. Slatkin, K. L. Mealey and N. C. Pedersen. 2004. Breed distribution and history of canine mdr1$1 \Delta$, a pharmacogenetic mutation that marks the emergence of breeds from the collie lineage. Proc Natl Acad Sci USA. 101(32): 11725-11730. 
Nelson, O.L., E. Carsten, S.A. Bentjen and K.L. Mealey. 2003. Ivermectin Toxicity in an Australian Shepherd Dog with the MDR1 Mutation Associated with Ivermectin Sensitivity in Collies. J Vet Intern Med. 17(3):354-356.

Norman, T.E., M. K. Chaffin, P. L. Norton, M. C. Coleman, W. B. Stoughton and T. Mays. 2012. Concurrent Ivermectin and Solanum spp. Toxicosis in a Herd of Horses. J Vet Intern Med. 26:1439-1442.

Nwoha, R. I. O. 2011. A case report on scabies in a goat. Clin. Rev. Opinions. 3(5):51-54.

Omura, S. 2008. Ivermectin: 25 years and still going strong. Int $\mathrm{J}$ Antimicrob Agents. 31(2): 91-98.

Otranto, D., G. Johnson, K. Syvrud, S. Yoon, J. S. Hunter and S. Rehbein. 2016. Treatment and control of bovine hypodermosis with ivermectin longacting injection (IVOMEC® GOLD). Parasites \& Vectors 9 (551): 1-6.

Page, N., C., de Jaham and M. Paradis. 2000. Observations on topical ivermectin in the treatment of otoacariosis, cheyletiellosis, and toxocariosis in cats. Can Vet J., 41(10):773-776.

Panahi, Y., Z. Poursaleh and M. Goldust. 2015. The efficacy of topical and oral Ivermectin in the treatment of human scabies. Annals of Parasitology, 61(1): $11-16$

Patel, P. K., S. K. Patel, S. Bhatt, D. Deepak, A. Prabhakar, B. Patel, C. Rabha and and S. K. Dixit. 2018. Therapeutic Management of Ivermectin Toxicity in a Calf: A Case Report. Int. J. Curr. Microbiol. App. Sci., 7(04): 1964-1969.

Pena-Espinoza, M., S. M. Thamsborg, M. J. Denwood, M. Drag, T.V. Hansen, V. F Jensen and H.L. Enemark. 2016. Efficacy of Ivermectin against gastrointestinal nematodes of cattle in Denmark evaluated by different methods for analysis of faecal egg count reduction. International Journal for
Parasitology: Drugs and Drug Resistance. 6: 241-250.

Plummer, C. E., M. E. Kallberg, F. J. Ollivier, D. E. Brooks and K. N. Gelatt. 2006. Suspected ivermectin toxicosis in a miniature mule foal causing blindness. Vet Ophthalmol. 9(1):29-32.

Pooda, H.S., R. Jean Baptiste, D. F. de Sale Hien, T. Lefèvre, S. R. Yerbanga, Z. Bengaly, R. K. Dabiré, A. M. G. Belem, I. Sidibé, P. Solano and K. Mouline. 2015. Administration of Ivermectin to peridomestic cattle: a promising approach to target the residual transmission of human malaria. Malaria Journal. 14 (496):1-12.

Prasad, V. and K.M. Koley. 2006. Treatment of Worm Infestation. In: Synopsis of Veterinary Pharmacology and Toxicology. (1st edn), Vahini Publications, India, pp. 235-260.

Prichard, R., C. Ménez and A. Lespine. 2012. Moxidectin and the avermectins: Consanguinity but not identity. Int. J. Parasitol. Drugs Drug Resist., 2: 134153.

Puspitasari, S., A. Farajallah, E. Sulistiawati and Muladno. 2016. Effectiveness of Ivermectin and Albendazole against Haemonchus contortus in Sheep in West Java, Indonesia. Tropical Life Sciences Research. 27(1): 135-144.

Puspitasari, S., E. Sulistiawati, M. Basar and A. Farajallah. 2015. Efektivitas Ivermectin dan Albendazole dalam Melawan Ostertagia pada Anakan Domba di Bogor, Indonesia. Jurnal Ilmu Pertanian Indonesia (JIPI) 20 (3): 257-264.

Radostits, O. M., G. C. Gay, D. C. Blood and K. W. Hinchkiliff. 2000. Veterinary Medicine 9th ed. EIBS and Bailliere,Tindal.

Rahman, M. M., M. A. Hossain and M. R. Alam. 2009a. Clinical Evaluation of Different Treatment Regimes for Management of Myiasis In Cattle. Bangl. J. Vet. Med. 7 (2) : $348-352$ 
Rahman, M. M., M. Mostofa, V. G. Barman, R. Mian and S.A. Mamun. 2009b. Comparative Efficacy of Dadmardan, Neem And Ivermectin Against Skin Lesions In Calves And Goats Bangl. J. Vet. Med. 7(1) : $275-280$

Rahman, M.M., A. Kabir, M.K. Islam, M.S. Rahman, M.S. Yasmin, F. Alom, M.A. Islam, S. Ahmed, M.R. Islam and M.H. Islam. 2017. Prospects and genesis of the versatile antiparasitic drug Ivermectin and its unsurpassed beneficial impact in Human and Veterinary Medicine. Int. J. Nat. Sci. 6(3):132-140.

Rahman, M. M. and M. A. Samad. 2010. Prevalence of subclinical gastro-intestinal parasitosis and their effects on milk production with therapeutic management in red chittagong cattle. Bangl $\mathrm{J}$ Vet Med., 8(1): 11-16.

Raunelli, F. and S. Gonzales. 2009. Strategic control and prevalence of fasciola hepatica in Peru: a pilot study. Int. J. App. Res. Vet. Med. 7(4):145-152.

Reinemeyer, C.R. and C. H. Courtney. 2001. Antinematodal drugs. In: Adams HR, editor. Veterinary pharmacology and therapeutics. Ames: Iowa State University Press., 2001. p. 963-69.

Roberson, F.L. 1988. Antinematodal drugs. In: Veterinary Pharmacology and Therapeutics. Booth, N.H. and McDonald, L.E. (eds), 3rd Ed. Iowa State University Press, Ames, Iowa. pp. 340345 .

Rothen-Weinhold, A., M.D. Gurny and M. Dahn. 2000. Formulation and technology aspects of conrolled drug delivery in animals. Pharm Sci Technol Today 3:222-31

Sanford, S.E., A.J. Rehmtulla and G.K.A. Josephson. 1988. Ivermectin Overdose and Toxicosis in Neonatal Pigs. Can Vet J. 29 (9): 735-736.

Saqib, M., G. Abbas and M.N. Mughal. 2015. Successful management of Ivermectin induced blindness in an African lion
(Panthera leo) by intravenous administration of a lipid emulsion. BMC Veterinary Research. 11 (287): 1-7.

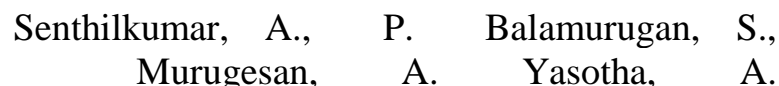
Shanmugasundram and N. Sribalaji. 2016. Clinical Features, Diagnosis and Treatment of Unusual Case of Cutaneous Stephanofilariasis in Crossbred Dairy Cattle. International Journal of Science, and Technology. 5 (4): 2045 - 2049.

Shoop, W. L., B. Michael, J. Egerton, H. Mrozik and M. Fisher. 2001. Titration of subcutaneously administered eprinomectin against mature and immature nematodes in cattle. J. Parasitol., 87 (6): 1466-1469.

Siroka, Z. and Z. Svobodova. 2013. The toxicity and adverse effects of selected drugs in animals - overview. Polish Journal of Veterinary Sciences. 16 (1): 181-191.

Sivine, F., C. Plume and M. Ansay. 1985. Picrotoxin, the antidote to ivermectin in dogs?. Vet Rec. 116 (7):195-196.

Stapley, E.O. and H. B. Woodruff. 1982. avermectin, antiparasitic lactones produced by Streptomyces avermitilis isolated from a soil in Japan. In: Umezawa, H., Deamin, A.L., Hata, T., Hutchinson, C.R. (Eds.), Trends in Antibiotic Research. Japan Antibiotics Research Association, Tokyo, pp. 154170.

Steel, J.W. 1993. Pharmacokinetics and metabolism of avermectins in livestock. Veterinary Parasitology, 48 (1-4): 45-47.

Swor, T. M., J. L. Whittenburg and M. K. Chaffin. 2009. Ivermectin toxicosis in three adult horses. J Am Vet Med Assoc. 235 (5): 558- 62.

Teare, J. A. and M. Bush. 1983.Toxicity and efficacy of ivermectin in chelonians. Journal of the American Veterinary Medical Association. 183 (11): 11951197. 
Thiripurasundari, M., K. Sathya, A. Uma, M. R. Srinivasan and P. Rajasekar. 2014. A Comparative Study on the Toxicity of Ivermectin in Zebra Fish and Catla Fish Models. Indo American Journal of Pharm Research. 4(09): 3683-3688

Watchko, J.F., M.J. Daood, B. Mahmood, K. Vats, C. Hart and M. Ahdab-Barmada. 2001. P-glycoprotein and bilirubin disposition. J Perinatol. 21 (Suppl 1): S43-S47.

Wolstenholme, A. J. 2011. Ion channels and receptor as targets for the control of parasitic nematodes. International Journal for Parasitology: Drugs and Drug Resistance. 1(1): 2-13.

Wosu, M. I. and A. I. Onyeabor. 2015. Use of Ivermectin in the Therapy of Sarcoptic Mange in West African Dwarf Goat: A Case Report. J. Vet. Adv. 5(6): 10141016.

Xiang, W. S., J. D. Wang, M. Wang and X. J. Wang. 2010. New nemadectin congener from Streptomyces microflavus neau3: fermentation, isolation, structure elucidation and biological activities. $\mathbf{J}$ Antibiot (Tokyo). 63 (4):171-175.

Yas-Natan, E., M. Shamir, S. Kleinbart and I. Aroch. 2003. Doramectin toxicity in a collie. Veterinary Record 153 (23): 718720.

Yates, D. M., V. Portillo and A. J. Wolstenholme 2003. The Ivermectin receptors of Haemonchus contortus and Caenorhabditis elegans. International Journal for Parasitology. 33 (11): 11831193.

Zalizar, L. 2017. Helminthiasis saluran cerna pada sapi perah. Jurnal Ilmu-Ilmu Peternakan. 27 (2): 116 - 122.

Zaman, M. A., T. U. Rehman, R. Z. Abbas, W. Babar, M. N. Khan, M. T. Riaz, R. Hussain, T. Ghauri and M. Arif. 2017. Therapeutic potential of Ivermectin, doramectin and trichlorophan against Psoroptes ovis in sheep and cattle of Cholistan. Pak Vet J. 37(2): 233-235. 